\title{
“DO YOU WANNA PLAY A GAME?". ESPACIO Y NIVELES \\ DE IMPLICACIÓN DEL PÚBLICO \\ EN LA REPRESENTACIÓN ESCÉNICA DEL GÉNERO TERRORÍFICO ${ }^{1}$
}

\author{
“DO YOU WANNA PLAY A GAME?”. SPACE AND LEVELS \\ OF AUDIENCE'S INVOLVEMENT IN THE SCENIC \\ REPRESENTATION OF THE HORROR GENRE
}

\section{Miguel CARRERA GARRIDO}

Universidad Marie Curie-Skłodowska de Lublin (Polonia)

miguel.carrera@poczta.umcs.lublin.pl

Resumen: El teatro, muy a menudo excluido en los estudios sobre géneros comúnmente llamados no miméticos (el terror, lo fantástico, la ciencia ficción), puede, sin embargo, aportar mecanismos que caen más allá del alcance de otros medios como el cine o la narrativa. En concreto, el terror puede beneficiarse de la ruptura de la cuarta pared y la integración del público en el ámbito escénico. El artículo rastrea, en la teoría y en la práctica, los grados de tal asimilación y las posibilidades que se siguen para la recreación del terror en las tablas.

\footnotetext{
${ }^{1}$ Este texto se inscribe en el proyecto de investigación Lo fantástico en la cultura española contemporánea (1955-2017): narrativa, teatro, cine, TV, cómic y radio (FFI201784402-P).
} 
Palabras clave: Terror. Teatro. Cuarta pared. Inmersión. Participación.

\begin{abstract}
Theatre, very often excluded in studies on genres usually called non-mimetic (horror, the fantastic, science fiction), can, however, afford mechanisms that fall beyond the reach of other media such as film or narrative fiction. Specifically, horror can benefit from the breaking of the fourth wall and the integration of the audience into the scenic area. This article traces, both in theory and in practice, the degrees of this assimilation to the show and the possibilities that follow for the recreation of horror on the stage.
\end{abstract}

Key Words: Horror. Theatre. Fourth Wall. Immersion. Participation.

\title{
1. OBJETIVO Y PRECISIONES EPISTEMOLÓGICAS
}

En este artículo me propongo reivindicar el potencial del modo escénico para la expresión artística del género terrorífico. Secularmente relegada en las investigaciones sobre áreas de la ficción adjetivadas de insólitas, irrealistas, no miméticas o, con mayor vaguedad, fantásticas, urge determinar lo que la escena ha aportado a estas estéticas, y lo que aún está en condiciones de ofrecer. No pienso tanto en títulos, corrientes o motivos concretos cuanto en mecanismos de representación y comunicación que caen fuera del alcance de otros modos imitativos. Respecto a lo primero, abundan los trabajos — más que nada en el mundo anglosajón — que se esfuerzan por reivindicar el lugar y el legado de fenómenos de indiscutible impacto como el Grand Guignol o el teatro gótico (si se ciñe uno al terror) $)^{2}$. También en el dominio del hispanismo empiezan a proliferar los estudios que, cuestionando el canon y los prejuicios respecto a cualquier

${ }^{2}$ Véanse, por citar solo un par de ellos, los trabajos de Hand y Wilson (2002) y Frank (2001). 
alejamiento de la norma realista, se proponen historiar la presencia de géneros —o modos, según especialistas como Jackson (1981), Ceserani (1999), Aldana Reyes (2014a) u Ordiz Alonso-Collada (2014)³ - como lo fantástico, el terror y la ciencia ficción en las tablas ${ }^{4}$.

En cuanto a la vertiente más teórica, son de citar estudios como los de Richardson (2015), Jurković (2013) o, de nuevo en el orbe hispánico, De Beni (2012), Rubio (2015) y Carrera Garrido (2016, 2017), que, más allá del fin historiográfico, especulan en torno a las especificidades y limitaciones de estas formas ficcionales en la escena. A objetivos similares sirve el presente trabajo. Centrado en la estética terrorífica, su objeto no radica, con todo, en los obstáculos que se le plantean al género en su traslación al plano escénico, sino, por el contrario, en el provecho que puede extraer de las estrategias y los dispositivos propios de la representación teatral. El espacio, como punto de encuentro entre emisor y receptores y en cuanto generador de significados, juega, en este sentido, un papel clave, y es por eso por lo que lo tomaré como referencia de primer orden.

Por lo que respecta a posiciones de índole genérica, cabe puntualizar desde ya que concibo el terror, o lo terrorífico, como un

\footnotetext{
${ }^{3}$ De acuerdo con Ceserani (1999: 12), un modo sería un "conjunto de procedimientos retórico-formales, planteamientos cognoscitivos, temas, articulaciones de lo imaginario históricamente concretas y utilizables por los distintos códigos lingüísticos, géneros artísticos o literarios". Para no complicar las cosas, en las páginas que siguen restringiré el uso del vocablo modo a las formas de imitación fijadas por Aristóteles. En cambio, usaré indistintamente género y categoría para aludir al terror, lo fantástico y demás expresiones no miméticas y populares.

${ }^{4}$ Por limitarnos al ámbito español y los últimos años, véanse los volúmenes Historia de lo fantástico en la cultura española contemporánea (1900-2015) (2017) e Historia de la ciencia ficción en la cultura española (2018), ambos publicados en IberoamericanaVervuert. Dirigidos por David Roas y Teresa López-Pellisa, respectivamente, y atentos a los diferentes modos expresivos — el teatro, entre ellos-, de sus logros cabe destacar el más que apreciable corpus propuesto y la decidida apuesta por un enfoque transmedial. También Roas (2006: 103-115), en su libro De la maravilla al horror, incluye un capítulo sobre el drama gótico, en el que atiende a la polémica, iniciada en el teatro, entre los conceptos de terror y horror; y De Beni (2012: 114-117, 124-130) dedica sendos espacios a la escena gótica y al Guignol y su repercusión en España. Este último y López-Pellisa, por cierto, consagraron el primer número de 2014 de Brumal al teatro fantástico.
} 
género distinto de lo fantástico; coincidente en muchos de sus rasgos y expresiones, mas susceptible de un tratamiento específico. Es una postura que contrasta con la de muchos teóricos en el ámbito hispánico, aun el románico. La preferencia por el marco de lo fantástico es evidente en tales zonas, quedando el terror definido, con frecuencia, como una de las modalidades de tal categoría, o, en todo caso, situado a la sombra de ella. Esta visión se remonta a la de todo un modelo como Todorov (1981: 35), que destinaba la "pura literatura de horror" a la imprecisa área de lo extraño; o a la del anterior Vax (1965: 10-11), que ubicaba lo horrible y macabro en las "fronteras de lo fantástico". Bajo el magisterio de ambos, la tendencia posterior ha sido a mantenerlo en dichas cercanías o, en la línea de un Caillois (1970: 7) —para quien "la intervención de lo sobrenatural debe culminar en un efecto de terror"-, a identificarlo con lo fantástico (por mucho que se admitiera no todas las ficciones terroríficas incluyen en sus historias episodios o seres imposibles); los ejemplos en Francia, Italia, Perú, Argentina, México o España son múltiples: por restringirnos a los más nombrados, citemos a Bozzeto (2005) y Ceserani (1999), en el contexto románico, y al madrugador Belevan (1976), a Campra (2008), Morales (2004) y Roas (2011), en el hispánico.

Tal preeminencia de lo fantástico en las publicaciones de procedencia románico-hispánica difiere, a su vez, de la situación en los países de habla inglesa, donde, más allá de notorias excepciones - como las de Rabkin (1976) o Jackson (1981) — la categoría no ha gozado de demasiada fortuna, desplazada, precisamente, por la del terror (horror) o por la hoy muy popular de lo gótico ${ }^{5}$. A este respecto, es muy revelador que, en su reciente asedio al caso español, uno de los más entusiastas

\footnotetext{
${ }^{5}$ Para este texto, consideraré lo gótico como sinónimo de terror, al igual que, en términos generales, hacen los críticos de expresión inglesa - y también algunos de española, como Ordiz Alonso-Collada (2014)—, si bien descreo de que se haya de extender su referencia a cualquier producción que, mínimamente inspirada en la corriente original, vaya más allá de sus manifestaciones a fines del siglo XVIII y a lo largo del XIX. Cuando más, me parece que estamos ante una subclase del terror. Para un intento de marcar las diferencias entre ambas nociones, véase Bloom (2015).
} 
especialistas en el medio británico —Xavier Aldana Reyes (2017: 11-13), de la Universidad Metropolitana de Mánchester — cuestione la rentabilidad crítica de lo fantástico, poniendo en tela de juicio las posiciones de una indiscutible referencia en el ámbito como David Roas ${ }^{6}$.

Personalmente, no creo que una categoría deba imponerse a la otra, ni que ninguna cuente con más credenciales para prevalecer en el discurso crítico. Veo indispensable, eso sí, diferenciarlas, subrayar sus especificidades, para que su aplicación a los análisis sea lo más fructífera posible. Así, dependiendo de la naturaleza del objeto analizado y los fines del estudio concreto, será más adecuado acudir a un marco u otro. De ello es una muestra, de hecho, el presente trabajo, cuyas tesis sobre las virtudes de la representación escénica son aplicables al terror, pero no necesariamente a lo fantástico, el cual, como ya advirtiera Pavis (1998: 204) y matizara, años después, el aludido De Beni (2012: 66-79), se enfrenta a limitaciones de calado en la plasmación escénica de dos de los elementos nucleares del género: lo sobrenatural y la duda epistemológica.

No soy, huelga decirlo, el primero en señalar esta necesidad, o aportar razones que demuestren tanto la disparidad entre las categorías fantástica y terrorífica como la validez epistemológica de ambas. Mis convicciones se fundan en las reflexiones de voces como las de Losilla (1993), Barceló (1999), López Santos (2010), Díaz Olmedo (2011) u Ordiz Alonso-Collada (2014). Todas ellas, a contracorriente de lo más extendido en el dominio hispánico, coinciden en afirmar que nos encontramos ante líneas distintas, con tradiciones que se tocan en numerosos puntos, pero que, a la postre, conforman géneros disímiles ${ }^{7}$. El argumento es siempre el

${ }^{6} \mathrm{El}$ origen peninsular de Aldana no hace sino volver más palmario su alejamiento de la cultura madre y el acatamiento de la tradición crítica imperante en su país de adopción. ${ }^{7}$ Elocuentemente, las opiniones de todos estos autores se formulan desde posiciones extrarradiales, tanto en lo geográfico como en lo académico, profesional y genérico. Así, López Santos y Ordiz Alonso-Collada llegan a sus tesis desde el interés por la tradición de lo gótico, que quieren rastrear en el mundo hispánico. La segunda, por su lado, ha trabajado en varias instituciones tanto en Estados Unidos como en Reino Unido, lo cual, sin duda, ha afectado a su visión del asunto. Algo similar se podría decir de Elia Barceló, que ha desarrollado su labor académica en Austria y en quien, de todos modos, la faceta crea- 
mismo: al igual que existen relatos con elementos imposibles - también en el mundo figurado- que no suscitan reacciones de miedo ni en personajes ni en receptores, hay otros que causan tal efecto sin recurrir a lo sobrenatural. La clave reside en la forma y el nivel de amenaza percibidos por los sujetos de la ficción y, por extensión, por el público. En este sentido, es muy útil la oposición que propone Roas (2011: 94-107) entre miedo metafísico o intelectual y miedo físico o emocional. El primero, dice, es el propio de lo fantástico, por cuanto apunta a lo desconocido, lo racionalmente inexplicable, entendido como amenaza por irreductible a la lógica; mientras que el segundo se basa en elementos perfectamente concebibles en nuestra realidad que, sin embargo, atentan contra la integridad fisiológica y emocional de los personajes (y, figuradamente, también de los receptores). Esta especie de miedo, aclara Roas (2011: 95), "tiene que ver con la amenaza física, la muerte y lo materialmente espantoso", y, si bien se trata de "un efecto habitual en lo fantástico", no lo es "en todas sus manifestaciones"; en cambio, "está presente en aquellas obras [...] donde se consigue atemorizar al lector por medios naturales".

La distinción, ciertamente, es vital para marcar la diferencia entre lo fantástico y lo terrorífico. Partiendo de ella, se puede sostener que el factor físico y afectivo posee, en este último, un estatus equivalente al que ostenta lo sobrenatural en el primero, y que su comparecencia es preceptiva tanto en la representación como en la recepción del discurso. La respuesta resulta, sin duda, decisiva en las dos categorías; ahora bien, mientras que en la fantástica presenta una marcada dimensión intelectual -incluso filosófica - en el terror se prioriza la conmoción irracional, de corte instintivo. Como dice Barceló (1999: 100): "Lo terrorífico iría dirigido más bien hacia el mundo emocional del lector, hacia la provocación visceral de miedo, repulsión y rechazo frente a situaciones o fenómenos

dora se impone a la investigadora; cosa igualmente predicable de Díaz Olmedo, informático y ajeno a la academia. En cuanto a Losilla, sus reflexiones proceden del mundo de la crítica cinematográfica, donde los términos de terror o terrorifico han gozado, también en España, de mayor predicamento que en los estudios literarios o teatrales. 
que pueden proceder tanto del mundo 'real' como de lo 'fantástico"'. De ello se deduce, igualmente, el protagonismo del cuerpo y los sentidos, determinantes no solo para la constitución de la diégesis, sino también para su procesamiento; no en vano, se ha hablado del terror como uno de los body genres, en los que el dolor o el placer experimentados en el cuerpo de las víctimas son, hasta cierto punto, reproducidos o imitados por el receptor (Williams, 1991: 3-6). Por su parte, el referido Aldana Reyes (2014a: 7) sostiene, en otro trabajo, que, "by virtue of its sensationalist or shocking nature, [el terror/lo gótico] is inherently corporeal"; pues, como explica, "as an artistic mode, it naturally appeals to the body of readers or viewers, as well as their imagination and intellect".

Parece lícito, pues, concluir que lo que distingue al terror de lo fantástico, al menos en términos elementales, es el acento que aquel pone en lo físico y visceral, aspecto al que se subordinaría el resto de componentes, incluido el sobrenatural, que pasa a verse como facultativo, circunstancial. El terror, así las cosas, surge, no de la ruptura producida por el resquebrajamiento de lo real y posible, sino ante la perspectiva de sufrir un daño físico o emocional o, en todo caso, ante la visión de escenas de crueldad y tormento psíquico-corporal; sentimiento que se trasmite, filtrado, al receptor. Como señala Roas (2011: 95): “El lector — proyectado emocionalmente en el texto- comparte la angustia experimentada por los personajes ante la violencia y/o la muerte". La identificación es, efectivamente, otro de los ejes del género: cuanto más próximo se vea el lector/espectador a las vivencias y emociones de los sujetos de la ficción, más éxito habrá logrado la obra. En ello, como se verá, la vía elegida para figurar la diégesis — el modo — tiene mucho más peso de lo que parecería: en función de cuál se trate, las opciones para potenciar la implicación se multiplican. Tal es lo que pretende demostrar este artículo. 


\section{EL TERROR FICCIONAL: NARRATIVAY CINE FRENTE A TEATRO}

Una vez establecido el objetivo del presente estudio y formulados los principios teóricos básicos de lo que aquí se entenderá por género terrorífico, inicio mi exposición contraponiendo la escena a las dos formas imitativas que, tradicionalmente, se han creído más propicias para la representación de dicha categoría: la narrativa y el cine. Mi idea es cuestionar ciertas asunciones sobre las que se asienta esta presunta superioridad o, como poco, llamar la atención sobre algunos puntos insuficientemente ponderados a propósito de la escena y sus tratos con el terror artístico.

Si partimos de una idea del terror como la defendida en las páginas precedentes, en la que el cuerpo —o mejor, la violencia ejercida sobre esteocupa un lugar de privilegio, y la visualidad —así como otros aspectos asociados a los sentidos - se sugiere poco menos que un requisito para la consecución del efecto deseado, todos estaremos de acuerdo en que la narrativa adolece de serias limitaciones. La palabra, por muy trabajada que esté y evocadora que resulte, es un código opaco, que solo por convención representa imágenes y corporeiza situaciones (dejo a un lado los libros ilustrados). El escenario recreado a partir de ella no existe fuera de la mente del receptor: cada cual podrá imaginarlo a su modo; al fin y al cabo, no se trata sino de una simulación, de un juego figurativo tan dependiente de la colaboración del destinatario como expuesto a su reticencia. De lo que no cabe duda es que jamás podrá la narrativa aspirar a una imitación directa de la realidad, como hacen la fotografía o, en especial, el cine. Esto, que, por lo que atañe al suspense —otro de los ingredientes estrella, según Carroll (2005: 209), del género terrorífico-, no tiene por qué suponer una merma en la efectividad del relato, sí lo es en lo relativo a la representación de los aspectos sensibles y la respuesta asociada. En este punto, el cine posee un lenguaje, unos recursos y un planteamiento semiótico-pragmático en principio más adecuados. A ello se refiere el novelista Díaz Olmedo 
(2011: 27) cuando dice:

La literatura necesita ser leída para ser arte como tal. Es necesario un esfuerzo del lector para dar forma a las ideas expresadas por el autor [...]. Frente a la literatura, el cine es un medio en el que la responsabilidad de la creación cae únicamente en el lado del autor [...]. Mientras que el ritmo de una narración cinematográfica viene impuesto al espectador por el ritmo del montaje, es imposible imponer un ritmo a una obra literaria más allá del que quiera darle el lector.

En cuanto al potencial de ambos modos para producir reacciones irracionales en el receptor, sus palabras no pueden ser más sintomáticas:

Es un recurso muy empleado en el cine el usar sus mecanismos para asustar al espectador, mediante una aparición repentina acompañada por un golpe de música fuerte. Esto es algo imposible de lograr mediante la palabra escrita. Igualmente, gran parte del cine de terror consigue efectos viscerales en el espectador mediante unas imágenes crudas y desagradables, un efecto que es muy difícil de duplicar en la literatura (Díaz Olmedo, 2011: 27 [resaltado mío]).

Así es: el cine tiene a su disposición todo un arsenal de dispositivos, técnicos y procedimentales, que activan de forma instantánea, sin mediación del intelecto, el abanico de emociones y afectos distintivos del terror ${ }^{8}$. Ninguno sería eficaz, con todo, de no ser por la estructura mimética del modo. La equivalencia, en apariencia exacta, entre la cosa imitada y

${ }^{8}$ Cherry (2009: 53) enumera algunos de tales mecanismos: "point-of-view camera shots and framing, dark or chiaroscuro lighting, jump cuts and variations in pacing, visual (and often violent) spectacles that employ make-up, prosthetic, animatronic, digital and other special effects, and discordant or otherwise unsettling musical cues and other sound effects". 
los signos desplegados para su representación remite a un realismo de base, una trasparencia semiótica, que, desde Bazin, ha dado pie a un sinfín de discusiones entre los teóricos del cine (Pérez Bowie, 2008: 109-128). La espontaneidad con la que se acomete la descodificación del discurso audiovisual permite un acceso inmediato, casi automático, a la ficción, que refuerza la credulidad y la implicación del público. Ello le exime, como decía Díaz Olmedo, de la labor de imaginarse la diégesis, situándolo, a cambio, ante un ámbito que reconoce ipso facto; plano al que se verá arrastrado y del que le será difícil desentenderse, al considerarlo como continuación del suyo propio. "Las imágenes", como observaba Gubern (1979: 16-17) en su Antropología del cine de terror, "se imponen así al espectador con la autoridad de lo verdadero y sobre ese principio —el make-believe - se ha edificado todo el aparato industrial del cine concebido como espectáculo y generador de fantasías".

Hay quien opina que la mayor parte del público del cine de terror es adolescente (Cherry, 2009: 39). Aunque se trata de una apreciación discutible, es obvio que el género goza de gran popularidad entre los miembros de este colectivo. Acaso ello se deba, entre otras razones, a que, a diferencia de otros discursos, el terror, en la superficie, no exige más que la identificación emocional con los sujetos de la ficción para lograr sus objetivos. Tal hecho, tal facilidad, que ya en narrativa hace que la crítica lo tache de "género trivial, 'subliteratura' para público inculto y con pocas aspiraciones" (Barceló, 1999: 101), se las ve en la pantalla con toda suerte de reservas. Esto mismo, a la vez, es indicio del poder del celuloide para atrapar al receptor y hacerle vivir la experiencia poco menos que en carne propia; porque de esto es, a fin de cuentas, de lo que se trata: el terror, igual que la comedia, invita a una experiencia, más que a una reflexión, y aunque no descarta niveles más profundos, solo la comparecencia de aquella es indispensable.

Considerado de esta manera, y sin perder de vista el citado protagonismo que los sentidos y el cuerpo ostentan en el género, el modo cinematográfico se antojaría mucho más apropiado que el narrativo- 
literario para la expresión y recepción de lo terrorífico9 . A la relajación del ejercicio imaginativo-intelectual del receptor — superado por el impacto sensorial — y la naturalidad con la que se manifiesta la empatía cabría añadir, además, otro aspecto, nada baladí: la oportunidad de compartir las emociones y los afectos en tiempo real. En tal comunión se cifra otro de los pilares de la recepción fílmica, pues, al igual que ocurre en un filme humorístico, uno de terror acciona en la audiencia unos protocolos de actuación que, en su artificialidad, suponen uno de los placeres añadidos del consumo de esta especie de cine. Sobre ello dice Cherry (2009: 38):

[T] he responses one observes at horror film screenings (audience members screaming, jumping in fright, clinging onto their friends, averting their look at the screen, even shouting warnings at the characters or laughing) are to a large degree play-acting or pretence. It is a performance that is expected, if not demanded by the construction of the horror film itself.

Dicho histrionismo comunal pierde todo su sentido, como es lógico, en el disfrute individual, solitario, de una novela o de un cuento. En literatura, el alumbramiento de una communitas mínimamente similar solo es factible, me parece, en los recitales o lecturas en voz alta... los cuales, pese a todo, continúan asentándose, mayormente, en la evocación que cada oyente lleva a cabo de la narración, y apenas en lo que observan y experimentan todos conjuntamente. Nada que ver, en fin, con lo que sucede en una sala de proyecciones o en el salón de nuestra casa, frente a un televisor y acompañados de amigos o parejas.

Hay algo, de cualquier manera, que cae fuera del alcance tanto

${ }^{9}$ Por supuesto, todo es discutible, también esta afirmación. Yo mismo, en mi lectura de The Girl Next Door (1989), de Jack Ketchum, no podía imaginarme el horror que experimentaría al enfrentarme a la versión fílmica de la novela. Su visionado fue, sin embargo, decepcionante. Creo, pese a todo, que ello se debió a que 1) ya conocía la historia, y a que 2) la adaptación no pasa de mediocre. En este texto, sea como fuere, me sitúo en un plano teórico, no de impresiones individuales. 
de narrativa como de cine, y que solo se hallaría en el teatro: me refiero al contacto auténtico, basado en una contigüidad física entre emisores y receptores. Acabo de aludir a los recitales: su eficacia en términos de experiencia y emoción se debe, en buena medida, al hecho mismo de la enunciación - acometida, por lo general, con el concurso de técnicas importadas del arte interpretativo-; pero sobre todo a que se celebran en vivo, en presencia de un público con el que se comparte tanto el tiempo como el espacio. Es el planteamiento básico del teatro: da igual que no haya escenografía o que la encarnación de personajes, acciones y espacios sea precaria; en un contexto como el descrito se dan cita las condiciones elementales para la existencia de un diálogo genuinamente teatral: aparte de lo que Dubatti (2003: 9) llama convivio - “festín, convite, y por extensión, reunión, encuentro de presencias"-, confluyen en él las circunstancias espaciales y personales imprescindibles para la constitución del fenómeno dramático.

"Puedo tomar cualquier espacio vacío y llamarlo un escenario desnudo", leemos en The Empty Space, de Brook (2015: 21); “Un hombre camina por este espacio vacío mientras otro le observa, y esto es todo lo que se necesita para realizar un acto teatral". Así lo prueban, efectivamente, los recitales, que también llamamos, no en balde, lecturas dramatizadas: a un lado, alguien que, más que leer un texto, lo dota de vida; y al otro, un público que responde tanto desde el plano intelectual como el irracional: descodificando el discurso lingüístico y, simultáneamente, reaccionando con el instinto a los aspavientos, las modulaciones en la voz y los gestos de quien, amén de lector, es performer. Pensemos, sin ir más lejos, en el funcionamiento de un cuentacuentos infantil: ¿puede plantearse un evento de esta clase sin un mínimo de histrionismo en el orador? Y otra cosa, quizá más decisiva: ¿es posible concebirlo sin el ingrediente de apelación a la audiencia (cf. García Barrientos, 2012: 80-81; Dubatti, 2003: 30) e interacción con ella? Ambos aspectos remiten al modo de imitación teatral, y si bien la actuación se ha visto incorporada por el cine como una de sus señas de identidad, el otro atributo es intransferible a las demás vías 
de representación. Únicamente el teatro, fundado en el convivio, permite, como decía, la comunicación inmediata entre emisor y receptor, el contacto real entre el espacio de la figuración y el de la recepción; activo del que se aprovecha, en efecto, la narración oral y que, como se verá, ofrece una enorme eficacia a la expresión del terror artístico ${ }^{10}$.

En la escena, por si fuera poco, adquiere toda su dimensión, todo su potencial participativo y vivencial, lo que decíamos que ocurría en una sala de cine ante una película de risa o terror. La performance con la que el público exterioriza sus emociones — que se da también en otros géneros, como el lacrimógeno-, lejos de quedarse en el patio de butacas, se proyecta hacia la escena, estableciendo un estimulante diálogo con los actores; un intercambio bidireccional que hace tambalearse las convenciones de la representación tradicional. Las posibilidades que se agolpan tras la vulneración de dichas normas - sobre todo las referentes al espacio- es uno de los principales valores del teatro frente a otros modos de expresión, en especial en el área genérica que nos ocupa.

\section{EL ESPACIO ESCÉNICO Y EL TERROR}

Cabe apuntar, en todo caso, que no siempre la escena ha sabido o ha querido sacar partido de este activo, ni en el dominio que nos ocupa ni en general. Aun cuando abundan, en la Historia, los ejemplos de piezas que atraían al espectador a la representación — sobre todo en los estratos más populares-, la verdad es que la comunicación entre ambos polos ha pasado por momentos de escaso - incluso nulo - aprovechamiento, fortaleciendo un modelo de representación en el que, como dicen los más críticos, ni siquiera importaría que el público se levantara y se fuera de la sala (Machon, 2013: 27).

Este cambio de paradigma comenzó a gestarse con el inicio de la

\footnotetext{
${ }^{10} \mathrm{El}$ simple hecho de que sean las historias de miedo las más populares al calor de una hoguera y en la boca de un buen cuentista, dispuesto a agarrarnos del brazo en el clímax del relato, ya debería hacernos pensar...
} 
modernidad y la reinterpretación de los clásicos. Determinado por una relectura sui generis de la mímesis aristotélica y horaciana, el teatro fue paulatinamente alejándose de sus raíces rituales y su espíritu ceremonial, los cuales habían favorecido, en la Antigüedad, la integración de los asistentes, su participación activa, en el espectáculo. "En estos rituales", dicen Oliva y Torres Monreal (2005: 13), "los sistemas de comunicación eran intraficcionales, es decir, o todos bailaban, o todos se sumergían en el mismo espíritu participativo". El paso de los años y la creciente autoridad de preceptistas preocupados por el decoro, la verosimilitud y otras reglas de composición ${ }^{11}$ dieron como resultado, entre otras cosas, el momentáneo divorcio entre ambas esferas. Arquitectónicamente, ello se vio plasmado en la aparición del teatro alla italiana, que se convertiría, allá por el XVIII, en el modelo espacial por antonomasia del teatro occidental. Llamado a delimitar un lugar específico para la encarnación del universo ficcional y, así, evitar su confusión con el real, su instauración supuso el cierre de la mayoría de los canales para la interacción ${ }^{12}$. Esta, reducida a fórmulas como el aparte o el guiño (cf. García Barrientos, 2012: 78-80), fue sacrificada, por paradójico que ello pueda sonar, en aras de un mayor realismo en la imitación.

Uno podría pensar que lo que se perdió por el lado de la comunicación se recuperó por el de la autenticidad, y que el naturalismo de la escena, dominante en el XIX, habría de jugar a favor de la efectividad y realismo de los espectáculos. Así se entendió, a todas luces, durante un tiempo, hasta que la llegada de la fotografía, primero, y el cine, después, puso de manifiesto las carencias del teatro en este respecto: lo grotescos $y$,

\footnotetext{
${ }^{11}$ Es muy útil, para conocer los nombres y posturas más sobresalientes en la tradición de la teoría dramática, la introducción al reader Teoría del teatro, de María del Carmen Bobes Naves (1997: 9-27; 9-19 para lo que va de Aristóteles hasta las poéticas del Neoclasicismo).

12"En el escenario a la italiana", explica Pavis (1998: 171-172), "la acción y los actores están confinados en una caja abierta frontalmente a la mirada del público [...]. Este tipo de escenario organiza el espacio según el principio de la distancia, de la simetría y de la reducción del universo a un cubo que significa el universo entero por el juego combinado de la representación directa y de la ilusión".
} 
a la postre, estériles que se revelaban sus intentos de reproducir la realidad en todos sus detalles; tentativas que, en el peor de los casos, podían acabar distanciando al público de la historia figurada y volver la escena un ámbito artificial, anquilosado, carente de vida... cuando debería ser justo al contrario; y es que, como dice Gubern (1979: 17) al reparar en esta "paradoja de la 'ilusión de realidad", en la escena, a diferencia del cine, "los actores no son sombras, sino seres de carne y hueso, y el espacio escénico y los objetos son tridimensionales". Dicho de otra forma: el teatro no habría de esforzarse por recrear la vida, dado que él mismo está hecha de ella (cf. García Barrientos, 2012: 237).

La evolución de las artes escénicas en las dos últimas centurias ha obedecido, en buena parte, a la voluntad de recuperar esta vida perdida, aplastada por asunciones que, como el valor de la palabra, la preeminencia del texto escrito o el peso del dramaturgo, han ido enajenándolo de sus atributos originales. La reactivación de estos se ha abordado, con enorme frecuencia, desde la reflexión sobre el espacio, especialmente en lo tocante a la dialéctica entre sala y escena. El prurito de devolverlos a la convivencia e integración primordiales es, en efecto, lo que anima las empresas de directores y grupos como Artaud, Grotowski, el Living Theater o Kantor. Reunidos bajo el anhelo común de (re)ritualizar la representación, en su programa sobresale, igualmente, el de restituir el elemento lúdico, de celebración colectiva, que aquella solía tener. Con razón alude Innes (1993: 8-10) al primitivismo como uno de los rasgos definitorios la vanguardia teatral del pasado siglo; un culto a lo primitivo, desde luego, forjado desde la mirada actual de Occidente y, por lo tanto, cimentado en conceptos no siempre rigurosos — románticos, a menudo_- pero que no por eso ha desempeñado un papel menos crucial en la revitalización de la escena en la contemporaneidad $^{13}$; tanto es así que el proyecto de volver a los orígenes,

\footnotetext{
13"Even for anthropologists or ethnographers, the primitive is almost always seen through a western, contemporary prism; and creative artists freely reinterpret primitive models to serve aims that would be alien to the original culture", dice Innes (1993: 3); si bien añade: "this is far more than a cult of the superficially exotic and barbaric. In avant-garde drama [...], primitivism goes hand in hand with aesthetic experimentation designed to advance
} 
de recuperar la esencia del teatro sigue presente en las propuestas más rompedoras. Entre ellas cabe destacar las iniciativas más fecundas en el área del terror teatral, partidarias de una recreación de los afectos que trascienda - aunque sin desterrarlas - la trasmisión de una historia y la empatía con unos sujetos imaginarios. Persuadidas, también ellas, de la importancia de las relaciones espaciales y personales en el espectáculo, deben su eficacia al debilitamiento de barreras físicas y conceptuales, así como al progresivo énfasis en el protagonismo del espectador; procesos paralelos en los que se distinguen tres niveles o momentos que paso a comentar.

\subsection{Primer nivel o momento: destrucción del teatro alla italiana}

"El teatro es el lugar menos indicado para el drama", opinaba Kantor (2010: 176), para quien la institución erigida en torno a la representación escénica, con sus edificios consabidos y las convenciones asociadas al rito social, habrían hecho del acontecimiento escénico un acto frívolo, fósil e inofensivo. "Es imposible que el teatro, una institución aislada de la vida cotidiana, una especie de coto vedado similar a un museo, un lugar destinado y reservado para representar y dar cobijo a la FICCIÓN, sea el espacio idóneo para que la FICCIÓN y la VIDA puedan por fin entablar su diálogo", concluía (Kantor, 2010: 176; mayúsculas del autor).

La idea del polaco enlaza con la de Artaud, que exigía la destrucción de la escena concebida al modo europeo-burgués: igualando las nociones de crueldad y vida ${ }^{14}$, definía el espectáculo como plaga y purificación brutal de cuerpo y alma. Sin profundizar en las implicaciones de estas ideas — todas ellas relacionables, en mayor o menor medida, con la

\footnotetext{
the technical progress of the art itself by exploring fundamental questions".

${ }^{14}$ "Empleo la palabra crueldad en el sentido de apetito de vida, de rigor cósmico y de necesidad implacable, en el sentido gnóstico de torbellino de vida que devora las tinieblas, en el sentido de ese dolor, de ineluctable necesidad, fuera de la cual no puede continuar la vida" (Artaud, 1978: 116-117).
} 
ética y estética del terror ${ }^{15}$-, subyace en ambos autores un mismo deseo: sacar al público de su zona de confort, expulsarlo del dominio donde se ha acomodado y exponerlo a las emociones corporeizadas en las tablas; hacerle olvidar, en definitiva, que está en un teatro. En ello, el abandono de la configuración alla italiana, o al menos de la oposición frontal de público y actores, de su separación, es un primer paso básico.

Caben aquí, por lo pronto, disposiciones arquitectónicas envolventes como las que enumera Breyer (1968), o, de conservar la distribución acostumbrada, una mayor cercanía entre ambos polos; cosa que se puede conseguir recortando literalmente la distancia que los separa y haciendo del intercambio algo más íntimo. A la intimidad también contribuye la reducción de las dimensiones del espacio. Las dos posibilidades han sido exploradas a fondo en el teatro contemporáneo y poseen en el de terror un buen exponente: el Grand Guignol. Consistente en la representación de situaciones límite, abundantes en torturas y asesinatos, el auditorio que acogía los shows grandguiñolescos, con 293 asientos, era el más reducido de París en el momento de su inauguración, a finales del XIX. El dato, que podría explicarse, hasta cierto punto, teniendo en cuenta la peculiaridad de las piezas, su condición poco menos que clandestina, apunta al ambiente cuasi familiar de las funciones; algo sin duda buscado, como un recurso para involucrar al espectador y hacerle sentir testigo a la par que cómplice de los actos cometidos en el escenario. Como dice Jurković (2013: s. p.): "The audience in this small, dark and claustrophobic space, in an ecclesiastic and tense atmosphere, becomes a witness to the horrors enacted on the stage [...]. They [los espectadores] become the witnesses as well as potential doers of the crime"; por no mencionar que, muy a menudo,

\footnotetext{
${ }^{15}$ Como ha demostrado recientemente Aldana Reyes (2014b), y como prueban sentencias de Le théâtre et son double del siguiente tipo: "Como la peste, el teatro es el tiempo del mal, el triunfo de las fuerzas oscuras, alimentadas hasta la extinción por una fuerza más profunda aún" (Artaud, 1978: 34); o "Propongo un teatro donde violentas imágenes quebranten e hipnoticen la sensibilidad del espectador" (Artaud, 1978: 94). Para ahondar en la idea del terror como un género cuyo objetivo estriba, entre otras cosas, en expulsar al receptor de la zona de confort, cfr. Carrera Garrido (2018: 8).
} 
los espectadores de las primeras filas eran salpicados por la sangre de la escena, o incluso increpados por los actores ${ }^{16}$.

Claro que, desde los años del Guignol, ha habido otras muchas, y más radicales, tentativas de relativizar, aun anular, la brecha entre público y espectáculo. Algunas han seguido insistiendo en la proximidad; otras han extremado la intimidad del intercambio, no solo empequeñeciendo al máximo el espacio del encuentro, sino reduciendo este a un único performer y un espectador (de ahí los dramas one-to-one); mientras que la mayoría ha optado por la solución más obvia: trasladar la representación a espacios naturales o, en todo caso, que en nada recordaran al aspecto de una sala teatra ${ }^{17}$. Tsitouri (2012: 208) habla de la desterritorialización de la escena en nuestro siglo. Como escribe, "in the turn of the century the audience has been called to follow, literally, theatre performances staged in uncanny, peculiar places; bars, warehouses, apartments, school classes, railway wagons and buses, even toilets or a detention house during the nazi occupation are only some of the spaces which have welcomed theatre performance" (Tsitouri, 2012: 207).

Nótese el adjetivo "uncanny" (siniestros, ominosos) para referirse a los sitios de la representación; aunque la autora no trata en concreto del teatro de terror, consideremos los efectos de la desterritorialización en nuestro terreno: un montaje en un matadero, por ejemplo, o en un hospital arrasado, en el que se haga uso de las instalaciones y donde el público no

\footnotetext{
${ }^{16}$ Quigley (2011) habla, por su parte, de los desmayos de los espectadores durante el espectáculo como una forma de participación. Esto, de cualquier manera, tendría más que ver con el tercer nivel descrito en este artículo, así como con el intercambio, la performance, que mencionábamos al final del capítulo anterior.

${ }^{17}$ En este particular se habla de found spaces o, en un sentido un tanto diferente, sitespecific theatre, o sea, la organización de espectáculos en lugares específicamente pensados para la ocasión y destinados a una única obra; ámbitos urbanos o naturales que, desprovistos de límites definidos y ajenos a la distribución convencional, evoquen en el espectador significados diversos, adecuados a cada caso. Cfr. Molanes Rial (2017) y las reflexiones de Machon (2013: 123-142) en torno al espacio en las prácticas inmersivas. "You don't know what's the performance space and what's the everyday space", dice (Machon, 2013: 54).
} 
disponga de un emplazamiento asignado previamente; al contrario, que se vea forzado a moverse de un cuarto a otro, empujado por el desarrollo de la acción e incluso perdido en su trazado. Como dice Rubio (2015: 199) en alusión a los lugares prototípicos del terror: "los espacios teatrales deberían asimilarse a estos, siendo recorridos por los espectadores, sin que estos sepan en qué momento el horror se hará presente, produciendo así en ellos la sensación de incertidumbre y el miedo a lo desconocido a lo largo del trayecto". Algo semejante a lo descrito es, ni más ni menos, lo que yo mismo viví hace pocos días, en el espectáculo Nanä II: Redención (2018), de la compañía Con Alevosía Teatro ${ }^{18}$. Celebrado en las inmediaciones de Pola de Laviana (Asturias), los actores nos arrastraban como a prisioneros de guerra a una casa destartalada, en cuyas dependencias tenía lugar el drama. Si bien es cierto que, stricto sensu, estábamos más próximos a los tipos que describiré a continuación — dado que los asistentes éramos asumidos al estatus de personajes e interpelados en varios pasajes-, la interacción, en realidad, era escasa, y lo que primaba era la deslocalización del público (como que habíamos sido conducidos con las cabezas cubiertas...). Me sirve, en cualquier caso, para defender que la ruptura de la representación convencional, efectuada en un auditorio - artificial en su naturaleza y previsible en su funcionamiento- - es altamente eficaz para la activación de los afectos.

Cabe recordar de nuevo, en este punto, a Kantor, que, hablando de sus tentativas desterritorializadoras, alude así a los espectadores: "habían sido atraídos con tretas a ese LUGAR REAL, y abandonados en él a su suerte, sin la defensa ni la protección que normalmente dispensan la ILUSIÓN y la DISTANCIA” (Kantor, 2010: 199; mayúsculas del autor). Por desgracia, continúa, "[1]a amenaza, la exposición a la sorpresa y al peligro creó una especie de estado masoquista cada vez más insoportable; sobre todo porque ese nuevo placer del espectador, con sus dosis de escalofrío, era en realidad falso e inseparable de la certeza de que el peligro era ficticio y la amenaza fabricada y fingida"; ante lo cual resuelve: "Había

${ }^{18}$ http://www.conalevosiateatro.com/redencion [19/07/2018]. 
que buscar otras zonas vírgenes" (Kantor, 2010: 199-200).

Así, justamente, debe funcionar un teatro de terror que de verdad quiera explotar al máximo su especificidad, los mecanismos intransferibles del modo dramático: evitando que el público se relaje —como, de hecho, pasó a ratos en la pieza recién mencionada-, impidiéndole, a todo trance, acceder a reductos - mentales y materiales - en los que pueda afirmar su seguridad y repetirse que todo es mentira. Claro que es mentira; el teatro, aun así, tiene la facultad de jugar con los límites entre lo verdadero y lo falso como los demás modos no pueden, y es a esto a lo que debe, a mi entender, acogerse el terror en las tablas: más que a erigir una historia con ingredientes espeluznantes o desagradables - o aparte de ello-, a interpelar al público directamente, haciéndole partícipe de los eventos figurados, de forma que sienta resquebrajarse sus certidumbres ontológicas ${ }^{19}$. En esto consiste el segundo nivel o momento: la ruptura de la cuarta pared y el simulacro de fusión de planos de existencia; efectos que son el buque insignia de una línea en boga en los escenarios de Occidente - mas practicada desde hace mucho tiempo-: el teatro inmersivo.

\subsection{Segundo nivel o momento: el teatro inmersivo}

Estrechamente relacionada con la desterritorialización (como veíamos a propósito de Nanä), la inmersión del público lo lleva a penetrar, literalmente, en el espacio de los sujetos ficcionales. Cuestionando su acostumbrado papel contemplativo, se ve integrado en la acción, por medio de las apelaciones de los personajes y la atracción física hacia el ámbito ocupado por aquellos: el espacio dramático, como lo denomina García Barrientos (2012: 154) —fusión del escénico y el diegético o ficcional-,

\footnotetext{
${ }^{19}$ Los paralelismos con el funcionamiento del relato fantástico según la teoría de Todorov, fundada en la duda epistemológica, saltan aquí a la vista. Ello confirma que en absoluto se debe despreciar dicho marco al hablar del terror, así sea en la escena o en general. Ya en un trabajo anterior, relativo a las casas del terror — que en breve mencionaré-, se demostraba la validez de dichos principios para entender la eficacia de tales espectáculos/ dispositivos (Carrera Garrido, 2014: 149-155).
} 
o, en terminología de Pavis (1998: 174), el espacio lúdico o gestual, "construido a partir de la actuación" y "en perpetuo movimiento". Esta absorción no implica, aun así, que, como pretenden los más entusiastas de la inmersión (Machon, 2014: 44), el espectador se vuelva automáticamente activo, que disfrute de libertad para moverse a su antojo en el plano de la ficción, o que pueda alterar mínimamente el conjunto; como dice Bouko (2014: 264), "interactivity is a rather rare mechanism among immersive performances". Ello no obsta para que la conversión de la audiencia en ente escénico y el consiguiente solapamiento de esferas ontológicas tenga poderosos efectos, algunos propicios a la expresión del terror.

"To be inside the work, not just its physical and temporal space but inside it as an aesthetic, affective, phenomenological entity gives a different aspect to the idea of a point of view, and of action", reconoce White (2013: 16-17), mientras que la aludida Bouko (2014: 260) señala la fisicidad de la escena como factor decisivo respecto a otros modos: "Dramatic immersion distinguishes itself from literary immersion by the tangibility of the world into which the individual is plunged", dice, "as opposed to the world of literature into which the reader is absorbed". Es una precisión importante, extensible al cine y a la navegación por mundos virtuales (de cuya teorización proviene, no en vano, el término inmersión); por mucho que se desarrolle la tecnología 3D o que se fomente la impresión de estar sumergido en la ficción, siempre faltará, en estas formas imitativas, el contacto con cuerpos sólidos, inertes y, sobre todo, animados. En contraste, el teatro, arte corpóreo por excelencia, posee un inigualable potencial, susceptible de traducirse en experiencias sensoriales y afectivas de primer orden. Así lo demuestra, mejor que ningún otro, el teatro inmersivo. Según Machon (2013: 46), estamos ante "a particular strand of (syn)aesthetic practice", en el sentido de que "it manipulates the explicit recreation of sensation through visual, physical, verbal, aural, tactile, haptic and olfactory means" (Machon, 2013: 107). Gracias a esto, aun cuando el tránsito hacia el dominio ficcional no se efectúa sino en un nivel de simulación, se impone con incomparable fuerza la faceta visceral, 
que agita al asistente como lo haría en su existencia cotidiana y genera en su ánimo una idea de riesgo, de peligro físico, inconcebible en otros modos.

Es esta impresión de amenaza el aspecto más aprovechable en la formulación de una estética del terror específicamente teatral. Aunque aquella no se plasme en agresiones auténticas, sí que puede acoger todo un repertorio de interacciones con la audiencia que la hagan temer por su integridad. Contra esto, asegura Machon (2013: 40) que "in order to address challenges that might exist in the work and to open up the possibilities for involvement, there are 'rules of engagement' that underpin the experience, involving clear, even if tacit, guidelines [...] that make the immersive world a safe environment". Con todo y con eso, admiten los propios practicantes de teatro inmersivo que tal seguridad es relativa, y que, en la posibilidad de tocarse y suscitar una sensación de amenaza real, reside uno de los principales atractivos de esta forma teatral. Así lo explica, por ejemplo, Randy Weiner, productor del popular espectáculo inmersivo Sleep No More (2011), de la compañía británica Punchdrunk:

It's not safe. I guess, what we've created is an environment where really things can go wrong [...]; when you're safely on your own side, the audience is here and the performers there, that's one thing; but when you're right on top of each other [...], anything can happen, and that audience member who doesn't understand the rules can get too involved in a scene and a performer can get frustrated if an audience member is in their way ${ }^{20}$.

Parte de las palabras de Weiner las refrenda Shank (1992: 180) en su glosa de uno de los dispositivos de La Fura dels Baus, exponente

\footnotetext{
${ }^{20} \mathrm{La}$ cita procede de un vídeo documental producido por American Theatre Wing y titulado, simplemente, "Immersive Theatre". Se puede ver aquí: https://www.youtube.com/ watch? $v=$ C5i6vy3Lyw [19/05/2018]. En cuanto a las declaraciones reproducidas, se encuentran entre el minuto 10.05 y el 10.28.
} 
de desterritorialización e inmersión avant-la-lettre: SUZ/O/SUZ (1985). Representado en un almacén, los asistentes debían permanecer en movimiento para escapar de plataformas móviles y de los objetos que los performers les lanzaban: "Evidence of the danger became clear at the performance I attended when a spectator was hit on the knee by one of these objects", observa, y añade: "The spectators were also in danger of being hit by animal viscera and buckets of 'blood' which the performers throw at each other as they run through the audience".

Júzguese lo que una interacción de estas características, en la que el público siente en su propio pellejo el riesgo de ser agredido (aun si esta agresión no sea seria y existan medidas para evitar complicaciones genuinas), puede llegar a aportar a la modalidad del terror, en la que la violencia corporal ocupa, como sabemos, un lugar prominente. No es común, a decir verdad, notar las virtualidades de la escena inmersiva en este sentido $^{21}$ : la mayoría de testimonios se centra en los intercambios positivos y su espíritu revitalizador, que redundaría en un mejor entendimiento del otro y en la reconexión con el propio yo. Bien, ello no tiene por qué ser siempre de esta manera: las emociones a priori negativas también pueden tener cabida y peso en esta área de la representación y comunicación escénicas. Pensándolo bien, hasta es posible que sean más productivas: a mi entender, el miedo, el terror, es una de las vías más inmediatas y fructíferas para alcanzar el chute adrenalítico que, en teoría, procura el teatro inmersivo; máxime cuando el show impone sus normas y el público se ve sometido a los caprichos de intérpretes y director.

Tampoco esta tiranía del espectáculo suele reconocerse al

${ }^{21}$ Una notoria excepción, hallada tras la primera versión de este texto, serían los artículos —no académicos, eso sí- de Winters (2017a, 2017b) alojados en el portal Haunting (https://www.haunting.net). De reciente creación y expresamente consagrado al teatro de terror inmersivo, es una valiosa guía para los espectáculos celebrados en Norteamérica. También en España existe una comunidad de semejantes características - Ocio Terror (https://ocioterror.es/)_, cuya presentación no puede ser más reveladora: “Tu guía de experiencias de terror: escape room de terror, pasajes, eventos Halloween, teatro inmersivo y mucho más". 
caracterizar el teatro de inmersión: como si admitir su existencia significase devolver al espectador al estado de alienación en el que, presuntamente, se hallaba antes de la ruptura de la cuarta pared. Lo cierto, empero, es que muchos de estos montajes, aun atrayendo al respetable al plano de la ficción, siguen manteniéndolo a raya, diferenciado de los verdaderos actores y con un escaso margen de movimiento, sujeto a las disposiciones de un plan predeterminado. Es algo que, en situaciones extremas - cuando todo ha sido predispuesto y la flexibilidad es nula-, puede generar reacciones opuestas a las que, en principio, se perseguían: ansiedad, inhibición, rechazo, etc. "Whether incorporated into the imaginary world, as in immersive theater, or kept at a distance [...], the individual is often subjected to a fear-inducing aesthetic which inhibits his actions", confirma Bouko (2014: 266), que poco más abajo añade que "the dramaturgy of anxiety is better suited to inhibiting the participant than to encouraging proactive behaviour" (Bouko, 2014: 267).

Sin duda, es una perspectiva desalentadora para quienes reivindican la autonomía y capacidad de decidir del público inmerso. Para nosotros, por el contrario, dicha "estética del miedo" — como la bautiza la misma investigadora (Bouko, 2014:266) — se sugiere especialmente oportuna. Los espectadores asumen el papel de víctima, como personajes arquetípicos de una ficción de terror, $\mathrm{y}$, expuestos a lo que el recorrido les depara, se dejan arrastrar de un sitio a otro, regocijándose — por paradójico que esto pueda parecer - con la sensación de amenaza y cerco constantes. Tal es la lógica, por ejemplo, de los túneles, pasajes o casas del terror (haunted attractions, en inglés, o simplemente haunts), forma escénica que, no por ubicarse en zonas alejadas de la producción artístico-cultural y estar asociada a la industria del entretenimiento, deja de presentar todos los rasgos del teatro inmersivo; de encarnar, de hecho, la mejor realización de este en la esfera de lo terrorífico (cfr. Carrera Garrido, 2014 y Winters, 2017a).

Las casas del terror, por si fuera poco, incorporan un ingrediente sistemáticamente desdeñado en las iniciativas más vanguardistas, o posdramáticas: el mantenimiento de la diégesis, aun de una línea 
argumental, a lo largo de la duración de la experiencia 22 ; detalle que garantiza, en toda su dimensión, el desdoblamiento inherente al fenómeno dramático, y permite a los asistentes disfrutar tanto de lo vivido en carne propia como de lo narrado en el relato. En otras palabras: conservan lo mejor de la lectura o el visionado de una obra de terror, con todos sus valores estéticos y emocionales, con sus personajes e intrigas, y le añaden el impacto de la vivencia.

La inmersión así considerada constituye, en resumidas cuentas, una potente vía para la canalización del terror en las tablas. Merced a ella, el público se ve arrojado, en primera persona, a universos de pesadilla, que lo rodean y hostigan en todos y desde todos los sentidos. Que su albedrío esté recortado y su bienestar (o malestar) dependa de otros agentes no se sugiere aquí como un problema, ni supone, en modo alguno, una regresión al lugar pasivo y, sobre todo, distanciado que solía ocupar en el teatro convencional; lejos de eso, este nuevo papel conviene a la perfección al género estudiado.

No siempre es así, cabe conceder, y del mismo modo que en el cine o la literatura de terror existen héroes, personajes activos, que luchan contra los monstruos y desvelan los enigmas, también en el teatro es factible reforzar la agencia, o capacidad de actuación, del espectador, haciendo de él un participante, (casi) al mismo nivel que los personajes de la ficción. Es lo que White (2013) llama estética de la participación o invitación, y que, como vimos, puede darse o no en la inmersión. Se trata del tercer, y definitivo, nivel o momento en el uso del espacio y la interacción para la

\footnotetext{
${ }^{22} \mathrm{El}$ abandono de una idea de narración clásica es, en efecto, una de las constantes en el teatro inmersivo, relacionada con el rechazo de la palabra o el texto previo (Machon 2013: 97). Incluso cuando las propuestas parten de obras clásicas - como es el caso de Sleep No More, inspirada en Macbeth, o, del mismo grupo, The Masque of the Red Death (2007), basado en el cuento de Poe_- "the narrative remains opaque" (Worthen, 2012: 91). La inmersión del espectador en el ámbito escénico, por otro lado, abre la puerta a la improvisación y las modificaciones de una representación a otra. Este, dice Machon (2013: 63), "is able to fashion her own 'narrative' and journey"; y aunque sabemos que esto no siempre ocurre, es cierto que no abundan las estructuras estables o racionalmente organizadas de la acción.
} 
creación de emociones y afectos propios del terror estético. Veámoslo en el siguiente, y último, apartado.

\subsection{Tercer nivel o momento: la participación}

De acuerdo con el aludido White, el teatro participativo es común en contextos infantiles o educativos; también se ha usado con fines de concienciación política, como evidencia el Teatro del Oprimido de Augusto Boal, o como vía para recuperar el carácter ceremonial de la escena; cosa de lo que serían buenos ejemplos montajes como Paradise Now (1968), del Living Theater, o las experiencias del último Grotowski. Por mi parte, sugiero que la estética de la participación es aplicable a un teatro cuyo fin primero consista en aterrar al espectador; sin reducirlo, eso sí, al papel de víctima que recién veíamos. Aquí este se ve investido de un horizonte de participación mucho mayor que en una función al uso o solo inmersiva. De tal horizonte dice White (2013: 59) que, como el de expectativas de Jauss y Gadamer, "is a limit and a range of potentials within that limit, both gaps to be filled and choices to be made"; pero, a diferencia de aquel, "these gaps and choices are about action rather than interpretation". Es decir: ya no es que se autorice o siquiera se anime a la concurrencia a participar; es que su intervención es vital para el éxito de la obra, en ella reside su razón de $\operatorname{ser}^{23}$.

Esta colaboración se ha comparado con la hipótesis de la opera aperta propuesta por Eco para la literatura (cf. Machon, 2013: 113-116) y, en general, con los esfuerzos del lector para interpretar el sentido último de una pieza, los cuales lo convertirían en una suerte de coautor de esta. En el teatro, la participación permitiría al espectador abandonar de una vez por todas su tradicional rol pasivo e incorporarse al ámbito escénico como un sujeto más de la representación, dotado de los mismos atributos

\footnotetext{
${ }^{23}$ Aunque se presente como una gradación, cabe aquí advertir que, igual que antes mantenía que no toda inmersión es participativa, tampoco toda participación es inmersiva (White, 2013: 169; Machon, 2013: 99).
} 
y privilegios que los seres de la ficción. Si en la inmersión aún era patente, en muchos casos, la brecha entre ambos polos —o sea, la prevalencia de la cuarta pared ${ }^{24}$ - en el paradigma escrutado asistimos, se supone, al total derrumbamiento de barreras y a lo que muchos creen la democratización de la escena. Es el caso del mentado Boal, para quien el hecho mismo de ser espectador es una condición despreciable, por alienante, castradora, impositiva. Su visión remite no solo a la tiranía de los intérpretes sobre los que los observan, sino también a la del autor (dramaturgo o director) y su obra, que se presentaría, de acuerdo con esta concepción, ya acabada, lista para una recepción sin posibilidad de réplica:

Sí, esta es, sin duda, la conclusión: “"espectador”, qué mala palabra! El espectador es menos que un hombre y hay que humanizarlo y restituirle su capacidad de acción en toda su plenitud. Él debe ser también un sujeto, un actor, en igualdad de condiciones con los actores, que deben ser también espectadores. Todas estas experiencias de teatro popular persiguen un mismo objetivo: la liberación del espectador, sobre quien el teatro ha impuesto visiones acabadas del mundo [...]; el espectador del teatro popular (el pueblo), no puede seguir siendo víctima pasiva de esas imágenes (Boal, 1989: 58).

Postura parecida, más cercana en el tiempo, sostiene la especialista en one-to-one performances Rachel Zehiran (2009: 3), que piensa que en estas el espectador ha de tener el derecho "to collaborate (to greater or lesser degrees) with the performer so that the two people create a

\footnotetext{
${ }^{24}$ Es muy significativo, a este respecto, lo que apunta uno de los directores de Sleep No More - Felix Barret — sobre las máscaras que debían ponerse los espectadores: "Handing out the masks is like assigning seats in an auditorium. It establishes each individual as part of an audience, and creates a boundary between them and the action" (apud Worthen, 2012: 94). Por su lado, y en la misma línea, Worthen (2012: 95) cuestiona la supuesta agencia concedida al público: "We can eat the candy and wander the space, but we are less the agents of the performance than its furniture", comenta.
} 
shared experience - responsive and dialectic as opposed to imposed and prescribed"; mientras que Machon (2013: 120) defiende que "[t]his creative agency has the potential to lead to a political agency on an individual or collective level".

Opiniones como las citadas evidencian la confianza en el poder liberador, tanto en un plano estético como ideológico, de la ruptura de barreras. Este ha sido, no obstante, puesto en duda por el filósofo Jacques Rancière, para quien la abducción del espectador al ámbito escénico y la atribución de un papel activo en el drama no son garantía de su despertar crítico: este puede plantearse, arguye, desde su lugar acostumbrado, distanciado de la acción, en tanto que su expulsión de dicho coto puede conducir a la banalización. “¿Pero no podríamos invertir los términos del problema preguntando si no es justamente la voluntad de suprimir la distancia la que crea la distancia?" (Rancière, 2010: 18).

Para nuestros intereses, que la conversión del público en participante y cocreador del espectáculo resulte o no en su emancipación es algo, hasta cierto punto, irrelevante. Igual que antes defendía que su sometimiento a una serie de parámetros prefijados no tenía por qué ser improductiva, en cuanto podía revertirse en beneficio de una experiencia semejante a la que sufren los protagonistas de la ficción terrorífica, apuesto ahora por una forma de participación eminentemente lúdica, capaz de incrementar la intensidad de la vivencia sensorial y afectiva. Así, si vernos como víctimas desencadenaba las emociones elementales del terror, sabernos investidos de una carga de agencia, por limitada que esta sea, supone una fuente de excitación adicional y un marcado énfasis en la condición de juego del intercambio teatral.

No conviene olvidar, a cuento de la cuestión de la agencia (o agentividad), que la teorización sobre la inmersión y la participación proviene, en buena medida, del universo de los videojuegos, y que uno puede ir al teatro solo para poner a prueba sus emociones y, en última instancia, pasárselo bien. Es un detalle que parecen subestimar los principales defensores de estas formas dramáticas, por cuanto, se diría, 
desacredita las pretensiones artísticas, intelectuales, ideológicas, de los espectáculos más experimentales y exigentes. En ellos, no solo se llama al público a jugar, sino que, en línea con lo que quería Boal, se busca hacerle olvidar del todo su estatus espectatorial. Al respecto, es revelador el juicio de Machon (2013: 68-69) sobre los "Murder Mystery Breaks" (juegos teatralizados al estilo cluedo). Si bien reconoce que son "fun, themed stays-away", en ellos, dice, "there is always a clear dividing line between fact and fiction, between spectator and event"; nada que ver, pues, con los genuinos espectáculos inmersivos-colaborativos, "which aim to blur the boundaries between life and art, and are carefully constructed as such".

Aceptando que, en principio, la diferencia en términos estéticos y discursivos es evidente, creo que la discriminación parte no tanto de una realidad cuanto de prejuicios relacionados, precisamente, con la modalidad de participación y, en no menor medida, con la temática y ámbito genérico de los espectáculos criticados (entre los que podríamos incluir los terroríficos, a menudo centrados en un asesinato); también con el hecho de que estos preservan de manera más palmaria la ficcionalidad, a menudo incluso una narrativa perfectamente discernible; y digo "más palmaria" porque creo que hasta en las empresas más experimentales y rupturistas prevalece una barrera entre lo que es real y lo que no. No importa lo movible o permeable que sea: siempre está ahí, haciendo de la indistinción total algo, en puridad, inalcanzable y, bien mirado, indeseable. Admitir lo contrario - esto es, llevar a sus últimas consecuencias la mezcla de esferas y atribuciones de los agentes - sería atentar contra la esencia del teatro, contra lo que lo distingue de otras ceremonias o rituales colectivos. Ello es predicable de los montajes inmersivos, pese a la convivencia física en un mismo espacio-tiempo - físico y ficcional-, pero también de los participativos, a despecho de la igualación que señalan sus teóricos y practicantes; y por si quedan dudas, aclara el propio White (2013: 160): "when we become audience participants we remain audience members"; y es que, explica, "the participant is simultaneously the performer, the one who enacts the performance through choice, the performance that emerges 
from their own body and the audience as they view it" (White, 2013: 161; cursiva del autor).

En resumen: la participación o colaboración del espectador plantea estimulantes posibilidades a una experiencia más directa del espectáculo, beneficiándose del carácter físico, tangible, de la escena, y generando en el espectador una impresión de agencia e indiferenciación de planos y roles. Esta, según algunos, puede dar lugar a la activación de su conciencia crítica, al verse liberado de las ataduras del teatro convencional. Ahora bien, tal liberación se basará siempre en un espejismo más o menos logrado: hasta en los casos de participación más activa, el asistente seguirá en su posición de mirante - así sea él quien hace avanzar la acción-, y actores, autores, directores, escenógrafos, en la de verdaderos artífices y trasmisores del conjunto, por abierto e interactivo que se presente. En cuanto a la ficcionalidad, se mantendrá como un factor diferencial: con independencia de lo lejos que se lleve la tensión con la realidad y por mucho que se distancie de una organización en forma de trama, su permanencia será condición sine qua non de la experiencia estética. Ello, sin duda, relativiza el potencial emancipador de la participación (sin desacreditarlo del todo, cabe advertir), mas no el meramente lúdico (que también reivindicaban, no lo olvidemos, los grandes vanguardistas del XX): el mismo se ve fortalecido, traído a un primer plano de importancia, en las experiencias que más nos interesan.

De nuevo, la práctica precede a la teoría, y existen multitud de propuestas que han dado el salto de la interacción básica que es asustar, asquear o agredir mínimamente ${ }^{25}$ a la exhortación a participar para que la

\footnotetext{
${ }^{25} \mathrm{O}$ no tan mínimamente. En uno de sus artículos, habla Winters (2017b) de los extreme haunts, donde el asistente firma un documento en el que da su consentimiento para ser vapuleado por los actores y sometido a todo tipo de vejaciones. El ejemplo más polémico en este sentido sería la atracción, situada en San Diego, McKamey Manor (https:// www.mckameymanor.com/). Criticada por el uso de violencia extrema - evidente en los vídeos promocionales ( $h t t p s: / / w w w . y o u t u b e . c o m / w a t c h ? v=v l 6 C G l B V p C A \& t=161 \mathrm{~s}$ [19/05/2018]) — es, aun así, uno de los lugares predilectos de los fans de esta forma escénica (los llamados haunters).
} 
acción progrese. El mecanismo se puede, en efecto, encontrar en muchos espectáculos interactivos actuales, que se precian de ser los primeros en incluir tal rasgo en sus montajes (como sería el caso de La Caja del Terror de Madrid, en cuya página leemos: "Siempre serás el protagonista de una historia llena de sorpresas y $100 \%$ inmersiva" ${ }^{26}$. No es, empero, ninguna novedad, ni en España ni, mucho menos, en el resto del mundo. Ya en las casas del terror más sofisticadas, el papel de los asistentes no se limitaba a gritar o salir huyendo; también se esperaba que tomasen ciertas decisiones y que, como en una de aquellas novelas de "Elige tu propia aventura" o en los videojuegos de aventura gráfica, se decantasen por un camino u otro, por una interacción u otra, por un acompañante u otro; todo ello para arribar al clímax de una ficción que se mantenía intacta. Sirvan como muestra, en el territorio peninsular, los montajes del grupo, también madrileño, Factoría de Terror: Llantos en la noche (2007) o Experimento Fear 2.0 (2009), sobre todo. En el último, ambientado en un psiquiátrico, se generaba la ilusión de integrar a los asistentes en pie de igualdad con los personajes, al requerirles, en pasajes puntuales, que actuasen o expresasen su opinión; mientras que en el otro, escenificado en los cuartos de una casa rural, los participantes debían ayudar al inspector protagonista a resolver un crimen $^{27}$. Sin llegar a encarnar a personajes individualizados de la diégesis — eventualidad no descartable, de todos modos-, su incursión no se limitaba, pues, a seguir dócilmente a los intérpretes y reaccionar a los estímulos; eran parte insustituible de la acción.

\footnotetext{
${ }^{26}$ https://www.lacajadelterror.com [19/05/2018].

${ }^{27}$ Actualmente, la compañía se halla inactiva y la página web ha sido dada de baja (si bien su creadora me ha confiado su deseo de volver pronto a la acción). Por suerte, aún se puede acceder al blog (http://elespectaculodelterror.blogspot.com [19/05/2018]) y a sus perfiles de Facebook (https://www.facebook.com/factoriadeterrormiedo y https://www. facebook.com/factoriadeterror [19/05/2018]), donde hay multitud de fotos y otros materiales de sus espectáculos.
} 


\section{CONCLUSIÓN PROVISIONAL: EL MÁS ALLÁ}

Espectáculos como los de la Factoría y, en menor medida, los de los otros grupos citados son interesantes porque reúnen los tres niveles presentados, sin renunciar a hilar una narración o despojar por completo al público de su faceta de mirante. Representan, así vistos, el más elevado grado de explotación del teatro en sus tratos con el terror físico; lo cual no significa que no exista un más allá, un escalón aún más hondo que, sin embargo, hace peligrar, ahora sí de manera preocupante, la naturaleza dramática de la experiencia. Lo hace, justamente, por extremar la vertiente participativa y lúdica del evento, al punto de colocar al otrora espectador en el centro de la acción y minimizar su rol de observador; haciendo de él el protagonista absoluto y proponiendo su interacción más como juego que como actuación, abierta a la contemplación. Pienso en iniciativas como las zombie walks o survival zombie ${ }^{28}$, los dark rides (suerte de montañas rusas temáticas) ${ }^{29}$, los juegos de rol en vivo (también llamados LARP, o Live Action Role Play) o, mejor aún, las escape rooms, que, a pesar de incluir, también ellas, las facetas descritas —es decir, la inmersión y la participación $^{30}$ - y presentar un hondo interés en el tema del espacio, caen

\footnotetext{
${ }^{28}$ Véase la página web del evento: http://survivalzombie.es. La cadena de televisión Dark lo presenta, en la suya, como "una experiencia inmersiva que nos da la posibilidad de cumplir nuestros deseos más macabros e irracionales", y comenta: "Cada semana, Survival Zombie conquista una ciudad española, convirtiéndola en el escenario de una película de terror post-apocalíptico, en el que los participantes deben procurar luchar con los 'buenos' y ganar a los 'malos"” (http://darktv.es/blog/5-los-pasajes-del-terrormas-perturbadores-del-planeta [19/05/2018]).

${ }^{29}$ Sobre esta forma, véase el interesantísimo artículo de Ndalianis (2010), cuyas tesis en torno a la estética del terror de Carroll (2005) y su sentido en los rides sirven, igualmente, para los espectáculos aquí descritos. Verbigracia: "Horror rides focus [...] on the affective assault on the participant [...]. For the horror rider, the fear of death and bodily destruction is one step closer to being a real threat" (Ndalianis, 2010: 22).

${ }^{30}$ Significativamente, la charla de TED titulada "The Power of Immersive Entertainment" cita las escape rooms como ejemplo de este paradigma (https://www.youtube.com/ watch? $v=X f H L 4 x$ Euolc $[19 / 05 / 2018])$. También la mencionada Caja del Terror incluye en su repertorio "La Criatura", una "terror escape room" inspirada en los mundos de Lovecraft (https://www.lacajadelterror.com/la-criatura [19/05/2018]); y si miramos a la
} 
del lado de lo parateatral; un dominio aún por explorar, sobre el que pesan, me temo, prejuicios de todo tipo, pero que, como los aquí escrutados, goza de una creciente popularidad y ofrece jugosas alternativas a la estética del terror. Así trataré de probarlo en futuros trabajos. En el que aquí termina se han examinado, en la teoría y en la práctica, las diversas vías por las que el teatro puede hacer llegar el terror al público sin perder su esencia; al contrario, sacando el máximo partido de las especificidades del modo escénico. La intención ha sido tanto teorizar en torno a estos extremos como visibilizar las realizaciones ya existentes. Sobre esta base, se pretende seguir construyendo un discurso crítico que normalice la presencia del teatro en los estudios hispánicos acerca de géneros no miméticos.

\section{REFERENCIAS BIBLIOGRÁFICAS}

ALDANA REYES, X. (2014a). Body Gothic. Corporeal Transgression in Contemporary Literature and Horror Film. Cardiff: University of Wales Press.

(2014b). "Artaud's Theatre of Affect: From Cruelty to Horror", Actual Virtual Journal 18.1, https://www.youtube.com/ watch? $v=U W d x Q 53 A 56 k$ [27/04/2018].

(2017). Spanish Gothic. National Identity, Collaboration and Cultural Adaptation. Londres: Palgrave Mcmillan.

ARTAUD, A. (1978). El teatro y su doble. Barcelona: Edhasa.

BARCELÓ, E. (1999). La inquietante familiaridad. El terror y sus arquetipos en los relatos fantásticos de Julio Cortázar. Wilhelmsfeld: Gottfried Egert Verlag.

BELEVAN, H. (1976). Teoría de lo fantástico. Apuntes para una dinámica de la expresión de la literatura de expresión fantástica. Barcelona:

citada comunidad Ocio Terror, veremos que esta forma ocupa un lugar prominente en la agenda y las reseñas recogidas. 
Anagrama.

BLOOM, C. (2015). "Horror Fiction: In Search of a Definition". En $A$ New Companion to the Gothic, D. Punter (ed.), 211-223. Oxford: Wiley-Blackwell.

BOAL, A. (1989). El teatro del oprimido. México D. F.: Editorial Patria. BOBES NAVES, M. del C. (1997). "Introducción a la teoría del teatro". En Teoría del teatro, M. del C. Bobes Naves (comp.), 9-27. Madrid: Arco / Libros.

BOUKO, C. (2014). "Interactivity and Immersion in a Media-Based Performance". Participations. Journal of Audience and Reception Studies 11.1, 254-269, http://www.participations.org/Volume\%20 11/Issue\%201/15.pdf [28/04/2018].

BOZZETTO, R. (2005). Passages du fantastiques: des imaginaires à l'inimaginable. Aix-en-Provence: Publications de l'Université de Provence.

BREYER, G. A. (1968). Teatro: el ámbito escénico. Buenos Aires: Centro Editor de América Latina.

BROOK, P. (2015). El espacio vacío. Barcelona: Península.

CAILLOIS, R. (1970). “Introducción”. En Antología del cuento fantástico, R. Caillois (ed.), 7-19. Buenos Aires: Sudamericana.

CAMPRA, R. (2008). Territorios de la ficción. Lo fantástico. Madrid: Renacimiento.

CARRERA GARRIDO, M. (2014). “Teatralidad y elementos fantásticos en las casas del terror". Brumal. Revista de investigación sobre lo fantástico 2.2 (monográfico "Teatro fantástico. Siglos XX y XXI"), 129-158, https://ddd.uab.cat/pub/brumal/brumal_a2014v2n2/brumal_a2014v2n2p129.pdf[27/04/2018]. (2016). "Miedo, teatro y España: soluciones a una ecuación insólita". En Territorios de la imaginación. Poéticas ficcionales de lo insólito en España y México, N. Álvarez Méndez, A. Abello Verano \& S. Fernández Martínez (eds.), 83-102. León: Universidad de León. (2017). "De los escenarios al celuloide (y vuelta): teatro y cine frente 
a la representación del terror fantástico". En Rappresentazioni del limite. Passaggi del fantastico tra letteratura e cinema, A. Boccuti (ed.), 67-89. Turín: Università degli Studi di Torino (Anejos de Artifara), http://www.aispi.it/wp-content/uploads/Anejos-1.pdf [28/04/2018].

(2018). "Fantástico y terror: teoría y práctica de dos categorías ficcionales en el ámbito hispánico". Studia Romanica Posnaniensia 45.2, 5-20.

CARROLL, N. (2005). Filosofía del terror o paradojas del corazón. Madrid, Antonio Machado Libros.

CESERANI, R. (1999). Lo fantástico. Madrid: Visor.

CHERRY, B. (2009). Horror. Londres \& Nueva York: Routledge.

DE BENI, M. (2012). Lo fantástico en escena. Formas de lo imposible en el teatro español contemporáneo. Pontevedra: Academia del Hispanismo.

DÍAZ OLMEDO, J. (2011). "Un posible futuro para la literatura de terror". Hélice. Reflexiones críticas sobre ficción especulativa 13, 23-27, http://www.revistahelice.com/revista/Helice_13.pdf [27/04/2018].

DUBATTI, J. (2003). El convivio teatral. Teoría y práctica del teatro comparado. Buenos Aires: Atuel.

FRANK, F. (2001). “Gothic Drama (1768-1830)”. En Gothic Writers: A Critical and Bibliographical Guide, D. H. Thomson y J. G. Voller (eds.), 147-164. Westport: Greenwood Press.

GARCÍA BARRIENTOS, J. L. (2012). Cómo se comenta una obra de teatro. Edición corregida y aumentada. México: PasodeGato / Toma, Ediciones y Producciones Escénicas y Cinematográficas.

GUBERN, R. (1979). "Primera parte". En Las raices del miedo. Antropología del cine de terror, R. Gubern \& J. Prat, 9-46. Barcelona: Tusquets.

HAND, R. J. \& WILSON, M. (2002). Grand-Guignol: The French Theatre of Horror. Exeter: University of Exeter Press.

INNES, C. (1993). Avant-Garde Theatre 1892-1992. Londres \& Nueva 
York: Routledge.

JACKSON, R. (1981). Fantasy: The Literature of Subversion. Londres: Methuen.

JURKOVIĆ, T. (2013). "Blood, Monstrosity and Violent Imagery: GrandGuignol, the French Theatre of Horror as a Form of Violent Entertainment". [SIC]-A Journal of Literature, Culture and Literary Translation 1.4 (“Coded Realities"), 1-15, https://www. sic-journal.org/ArticleView.aspx?aid=208 [28/04/2018].

KANTOR, T. (2010). "El lugar teatral”. En Teatro de la muerte, 149-212. Barcelona: Alba Editorial.

LÓPEZ SANTOS, M. (2010). El género gótico. ¿Génesis de la literatura fantástica? Alicante: Biblioteca Virtual Miguel de Cervantes, http://www.cervantesvirtual.com/obra-visor/el-genero-goticogenesis-de-la-literatura-fantastica/html/458dbc94-a0f8-11elb1fb-00163ebf5e63_6.html [07/07/2018].

LOSILLA, C. (1993). El cine de terror. Una introducción. Barcelona: Paidós.

MACHON, J. (2013). Immersive Theatres. Intimacy and Immediacy in Contemporary Performance. Nueva York: Palgrave Macmillan.

MOLANES RIAL, M. (2017). "El lugar del espectador en las prácticas sitespecific en la escena actual”. Don Galán. Revista de investigación teatral 7, http://teatro.es/contenidos/donGalan/donGalanNum7/ pagina.php?vol=7\&doc=1_9\&el-lugar-del-espectador-en-laspracticas-site-specific-en-la-escena-actual-monica-molanes-rial [28/04/2018].

MORALES, A. M. (2004). "Transgresiones y legalidades (Lo fantástico en el umbral)". En Odiseas de lo fantástico, A. M. M. \& J. M. Sardiñas (eds.), 25-37. México: Coloquios Internacionales de Literatura Fantástica.

NDALIANIS, A (2010). "Dark Rides, Hybrid Machines and the Horror Experience". En Horror Zone. The Cultural Experience of Contemporary Horror Cinema, I. Conrich (ed.), 11-26. Londres: I. 


\section{B. Tauris \& Co Ltd.}

OLIVA, C. \& TORRES MONREAL, F. (2005). Historia básica del arte escénico. Madrid: Cátedra.

ORDIZ ALONSO-COLLADA, I. (2014). "Estrategias ficcionales de lo insólito: la literatura gótica frente a la literatura fantástica". Badebec. Revista del Centro de Estudios de Teoría y Crítica Literaria 3.6, 138-168. https://revista.badebec.org/index.php/badebec/article/ view/73/68 [07/07/2018].

PAVIS, P. (1998). Diccionario del teatro. Barcelona: Paidós.

PÉREZ BOWIE, J. A. (2008). Leer el cine. La teoría literaria en la teoría cinematográfica. Salamanca: Universidad de Salamanca.

QUIGLEY, K. (2011). "Theatre On Call. Participatory Fainting and Grand Guignol Theatre". Performance Research 16.3, 105-107.

RABKIN, E. (1976). The Fantastic in Literature. Princeton: Princeton University Press.

RANCIÈRE, J. (2010). El espectador emancipado. Buenos Aires: Manantial.

RICHARDSON, J. N. (2015). Horror Theatre: Investing in the Aesthetics of Horror as a Theatrical Genre. Nueva York: Columbia University, https://academiccommons.columbia.edu/catalog/ac: 187704 [07/07/2018].

ROAS, D. (2006). De la maravilla al horror. Los inicios de lo fantástico en la cultura española (1750-1860). Pontevedra: Mirabel. (2011). Tras los límites de lo real. Una definición de lo fantástico. Madrid: Páginas de Espuma.

RUBIO, A. (2015). "El terror en el teatro". Reflexión Académica en Diseño y Comunicación 24, 198-199.

SHANK, T. (1992). "The Shock of the Actual: Disrupting the Theatrical Illusion”. En Staging the Impossible. The Fantastic Mode in Modern Drama, P. D. Murphy (ed.), 169-181, Westport: Greenwood Press. TODOROV, T. (1981). Introducción a la literatura fantástica. México D. F.: Premia. 
TSITOURI, R. (2012). “A [New] Space for Contemporary Drama?”. En Theatre Space After 20th Century. Thematic Proceedings of the 4th International Scientific Conference in the cycle "Spectacle-CityIdentity", R. Dinulovic, M. Krklješ \& O. Gracanin (eds.), 205-226. Novi Sad: Faculty of Technical Sciences.

VAX, L. (1965). Arte y literatura fantásticas. Buenos Aires: Editorial Universitaria de Buenos Aires.

WHITE, G. (2013). Audience Participation in Theatre: Aesthetics of the Invitation. Nueva York: Palgrave MacMillan.

WILLIAMS, L. (1991). "Film Bodies: Gender, Genre, and Excess". Film Quarterly 44.4, 2-13.

WINTERS, T. (2017a). "Why Immersive Theater Matters, What It Is, and How to Get Involved". Haunting, 2 de enero, https://www. haunting. net/immersive-theater-matters [07/07/2018].

(2017b). "The Appeal of Extreme Haunts, What They Are, and How to Start". Haunting, 18 de enero, https://www.haunting.net/ extreme-haunts [07/07/2018].

WORTHEN, W. B. (2012). “"The Written Troubles of the Brain': Sleep No More and the Space of Character". Theatre Journal 64.1, 79-97.

ZEHIRAN, R. (2009). "Introduction". En One to One Performance. A Study Room Guide on Works Devised for an "Audience of One", R. Zehiran (comp.), 3-7. Londres: Live Art Development Agency, http://www.thisisliveart.co.uk/resources/catalogue/rachelzerihans-study-room-guide [28/04/2018].

Recibido el 30 de abril de 2018.

Aceptado el 23 de julio de 2018. 